\title{
Apolipoprotein A5 IVS3+476A Allelic Variant Associates With Increased Trigliceride Levels and Confers Risk for Development of Metabolic Syndrome in Hungarians
}

\author{
Péter Kisfali; Márton Mohás, MD*; Anita Maasz; Ferenc Hadarits, MD**; Lajos Markó, MD*; \\ Katalin Horvatovich; Tamás Oroszlán, $\mathrm{MD}^{\dagger}$; Zoltán Bagosi, $\mathrm{MD}^{\dagger}$; Zoltán Bujtor, $\mathrm{MD}^{\dagger}$; \\ Beáta Gasztonyi, $\mathrm{MD}, \mathrm{PhD}^{\dagger}$; István Wittmann, $\mathrm{MD}, \mathrm{PhD}^{*}$; Béla Melegh, $\mathrm{MD}, \mathrm{PhD}$
}

\begin{abstract}
Background Metabolic syndrome consists of multiple risk factors that are increasing the cardiovascular mortality. The T-1131C variant of the apolipoprotein A5 gene, associated with increased triglycerides, has been found to confer risk for cardiovascular diseases and metabolic syndrome. Because other naturally occurring variants of the gene also correlate with elevated triglycerides, the possible role of 2 common variants, the IVS3+G476A and T1259C, with metabolic syndrome was investigated.

Methods and Results A total of 213 metabolic syndrome patients and 142 healthy controls were genotyped by polymerase chain reaction-restriction fragment length polymorphism. Serum triglycerides were increased in carriers compared with non-carriers in both groups $(\mathrm{p}<0.001)$; serum cholesterol levels were similar in all genotypes. The IVS3+476A allele frequency was increased in metabolic syndrome patients compared with controls ( 8.05 vs $2.47 \%$; $\mathrm{p}<0.05$ ), whereas the $1259 \mathrm{C}$ allele frequency did not differ between the groups. Multiple logistic regression analyses adjusted for age, gender, serum total cholesterol, acute myocardial infarction and stroke revealed that the IVS3 $+476 \mathrm{~A}$ variant confers risk for development of metabolic syndrome (odds ratio $=3.529$, $95 \%$ confidence interval $1.308-9.029, \mathrm{p}=0.009)$, but the $1259 \mathrm{C}$ allele had no such an effect.

Conclusions Carrying the IVS3+473A allele is associated with elevated triglycerides and confers risk for development of metabolic syndrome, a combination that represents increased risk for development of atherogenic vascular diseases. (Circ J 2008; 72: 40-43)
\end{abstract}

Key Words: APOA5; IVS3+G476A; Metabolic syndrome; Single nucleotide polymorphism; T1259C

$\Delta$

bdominal obesity, increased level of serum triglycerides and decrease of serum high-density lipoprotein-cholesterol (HDL-C), elevated blood pressure, and glucose intolerance (impaired fasting glucose, impaired glucose tolerance, or the presence of diabetes mellitus) are the major components of the metabolic syndrome! The prevalence of this syndrome is approximately $25 \%$ in adult males and $18 \%$ in adult females in the industrialized countries? The etiology of the syndrome is complex, and includes several environmental and genetic factors as well, such as lifestyle, physical inactivity, smoking, diet, ageing, and race ${ }^{3-5}$ This syndrome is very often associated with developing type 2 diabetes mellitus, or fatal cardio- and cerebrovascular events. 1,6

The recently identified apolipoprotein A5 (APOA5) gene

(Received August 2, 2007; revised manuscript received September 2, 2007; accepted September 14, 2007)

Department of Medical Genetics and Child Development, *2 $2^{\text {nd }}$ Department of Medicine and Nephrological Center, University of Pécs, Pécs, **Central Laboratory, Markusovszky County Hospital, Szombathely and $2^{\text {nd }}$ Department of Medicine, Zala County Hospital, Zalaegerszeg, Hungary

Mailing address: Béla Melegh, MD, PhD, Department of Medical Genetics and Child Development, University of Pécs, Pécs, Szigeti 12, H-7624, Hungary. E-mail: bela.melegh@aok.pte.hu

All rights are reserved to the Japanese Circulation Society. For permissions, please e-mail: cj@j-circ.or.jp is located on chromosome 11q23, approximately $27 \mathrm{~kb}$ downstream from the APOAI-CIII-AIV gene cluster and is involved in lipid metabolism, influencing the level of highdensity lipoprotein and very low-density lipoprotein (VLDL) particles? APOA5 is composed of 4 exons and encodes 366 amino acids? Several single nucleotide polymorphisms (SNPs) have been described for APOA5, among which T1131C, IVS3+G476A, T1259C and C56G are known to be associated with elevated triglyceride levels in several European $^{4,9-11}$ and Japanese populations, ${ }^{4,12}$ in addition, some of them are known to correlate with diseases as susceptibility genes for ischemic heart disease and stroke?, $, 8,13$ The T-1131C variant has been demonstrated also as a risk factor for metabolic syndrome4,14 As a natural extension, the aim of the current study was to test the possible role of the IVS3+G476A and T1259C variants in the development of metabolic syndrome.

\section{Methods}

\section{Study Population}

The study population comprised 355 individuals from the Hungarian population. A total of 213 metabolic syndrome patients (99 males, 114 females, mean age: $61.09 \pm 1.01$ years, range: $25-82$ years) were selected according to the criteria of the modified Adult Treatment Panel III of National Cholesterol Education Program whereby meta- 
Table 1 Major Clinical Parameters of the Patients With Metabolic Syndrome and the Control Subjects

\begin{tabular}{lcc}
\hline \hline & Metabolic syndrome patients $(n=213)$ & Controls $(n=142)$ \\
\hline Gender $(\mathrm{M} / \mathrm{F})$ & $99 / 114$ & $66 / 76$ \\
Age $($ years $)$ & $61.09 \pm 1.01$ & $59.53 \pm 1.43$ \\
BMI $\left(\mathrm{kg} / \mathrm{m}^{2}\right)$ & $31.99 \pm 0.52$ & $24.04 \pm 0.18^{*}$ \\
Serum $T G(\mathrm{mmol} / \mathrm{L})$ & $2.65 \pm 0.20$ & $1.45 \pm 0.04^{*}$ \\
Serum $T C(\mathrm{mmol} / \mathrm{L})$ & $5.49 \pm 0.12$ & $5.40 \pm 0.08$ \\
Serum $\mathrm{HDL}-\mathrm{C}(\mathrm{mmol} / \mathrm{L})$ & $1.22 \pm 0.02$ & \\
FPG $(\mathrm{mmol} / \mathrm{L})$ & $12.49 \pm 2.11$ & \\
SBP $(\mathrm{mmHg})$ & $140 \pm 1.27$ & \\
DBP $(\mathrm{mmHg})$ & $84.4 \pm 1.12$ & \\
\hline
\end{tabular}

BMI, body mass index; TG, triglycerides; TC, total cholesterol; HDL-C, high-density lipoprotein-cholesterol; FPG, fasting plasma glucose; SBP, systolic blood pressure; DBP, diastolic blood pressure.

Data are means \pm SEM. ${ }^{*} p<0.001$.

Table 2 Serum TGs and Serum TC in Patients With Metabolic Syndrome and in the Control Subjects According to the IVS3 + G476A and T1259C Variants of $A P O A 5$

\begin{tabular}{|c|c|c|c|c|c|c|c|c|}
\hline & \multicolumn{4}{|c|}{$I V S 3+G 476 A$} & \multicolumn{4}{|c|}{$T 1259 C$} \\
\hline & \multicolumn{2}{|c|}{ Metabolic syndrome patients } & \multicolumn{2}{|c|}{ Controls } & \multicolumn{2}{|c|}{ Metabolic syndrome patients } & \multicolumn{2}{|c|}{ Controls } \\
\hline & $\begin{array}{c}\text { Non-carrier } \\
(G G) \\
(n=180)\end{array}$ & $\begin{array}{c}\text { Carrier } \\
(G A+A A) \\
(n=33)\end{array}$ & $\begin{array}{c}\text { Non-carrier } \\
(G G) \\
(n=135)\end{array}$ & $\begin{array}{c}\text { Carrier } \\
(G A+A A) \\
(n=7)\end{array}$ & $\begin{array}{c}\text { Non-carrier } \\
(T T) \\
(n=179)\end{array}$ & $\begin{array}{c}\text { Carrier } \\
(T C+C C) \\
(n=34)\end{array}$ & $\begin{array}{c}\text { Non-carrier } \\
(T T) \\
(n=135)\end{array}$ & $\begin{array}{c}\text { Carrier } \\
(T C+C C) \\
(n=7)\end{array}$ \\
\hline Serum $T G(\mathrm{mmol} / \mathrm{L})$ & $2.31 \pm 0.11$ & $3.21 \pm 0.48 *$ & $1.40 \pm 0.03$ & $1.90 \pm 0.20^{* *}$ & $2.89 \pm 0.11$ & $3.28 \pm 0.47^{\#}$ & $1.34 \pm 0.03$ & $1.67 \pm 0.16^{\# \#}$ \\
\hline Serum TC $(\mathrm{mmol} / \mathrm{L})$ & $5.30 \pm 0.08$ & $5.78 \pm 0.27$ & $5.43 \pm 0.09$ & $4.86 \pm 0.30$ & $5.30 \pm 0.08$ & $5.80 \pm 0.26$ & $5.38 \pm 0.10$ & $5.38 \pm 0.26$ \\
\hline Serum HDL-C $(\mathrm{mmol} / \mathrm{L})$ & $1.22 \pm 0.02$ & $1.23 \pm 0.05$ & & & $1.21 \pm 0.02$ & $1.23 \pm 0.11$ & & \\
\hline$F P G(\mathrm{mmol} / \mathrm{L})$ & $12.49 \pm 2.11$ & $10.275 \pm 1.02$ & & & $12.89 \pm 2.52$ & $10.09 \pm 0.92$ & & \\
\hline$S B P(m m H g)$ & $140 \pm 2.05$ & $141 \pm 3.33$ & & & $140 \pm 2.38$ & $141 \pm 2.97$ & & \\
\hline $\mathrm{DBP}(\mathrm{mmHg})$ & $84.4 \pm 1.12$ & $81.2 \pm 3.98$ & & & $84.9 \pm 1.10$ & $82.2 \pm 3.64$ & & \\
\hline
\end{tabular}

APOA5, apolipoprotein A5. Other abbreviations see in Table 1.

Data are means \pm SEM. ${ }^{*} p=0.035 ;{ }^{* *} p=0.016 ;{ }^{*} p=0.016 ;{ }^{* \#} p=0.023$.

bolic syndrome was defined as the presence of at least 3 of the criteria listed: body mass index $(\mathrm{BMI})>25$ instead of waist circumference, serum triglycerides $\geq 1.70 \mathrm{mmol} / \mathrm{L}$; serum HDL-C $<0.9 / 1.1 \mathrm{mmol} / \mathrm{L}(\mathrm{M} / \mathrm{F})$; systolic blood pressure $\geq 130 \mathrm{mmHg}$ and diastolic blood pressure $\geq 85 \mathrm{mmHg}$; fasting plasma glucose levels $>5.60 \mathrm{mmol} / \mathrm{L} 2,15$ A total of 142 apparently healthy subjects ( 66 males, 76 females, mean age: $59.53 \pm 1.43$ years, range: $26-93$ years) without any single clinical or laboratory mark of metabolic syndrome served as controls. Serum HDL-C, fasting plasma glucose levels and systolic/diastolic blood pressures were not available for the controls. Neither the subjects with metabolic syndrome nor the controls were taking any medication at the time of investigation.

All participants gave their informed consent and the study was approved by the local Ethics Committee.

\section{Genetic Analysis}

Genomic DNA was isolated from peripheral blood leukocytes by a standard salting out procedure. The T1259C and IVS3+G476A SNPs of the APOA5 were genotyped by polymerase chain reaction-restriction fragment length polymorphism. To test the IVS3+G476A alteration the following oligonucleotides were used for amplification: 5'-CTC AAG GCT GTC TTC AG-3' and 5'-CCT TTG ATT CTG GGG ACTG G-3' (antisense) (Metabion, Martinsried, Germany). The PCR product $(15 \mu \mathrm{l})$ was digested with $1 \mathrm{U}$ of $M n l I$ restriction endonuclease (Fermentas, Burlington, ON, Canada) at $37^{\circ} \mathrm{C}$ overnight. The restriction fragments were analysed by $3 \%$ agarose gel stained with ethidium bromide (Fluka Chemie Gmbh, Buchs, Switzerland) and visualized on a UV transilluminator (Uvitec, Cambridge, UK). In the samples with GG genotype, the digestion resulted in $25 \mathrm{bp}, 114 \mathrm{bp}$, $141 \mathrm{bp}$ and in the homozygous samples $25 \mathrm{bp}, 41 \mathrm{bp}, 73 \mathrm{bp}$ and $141 \mathrm{bp}$ long products were detected.

The T1259C polymorphism were detected using the primers 5'-TCA GTC CTT GAA AGT GGC CT-3' and 5'-ATG TAG TGG CAC AGG CTT CC-3' (antisense) (Metabion). The PCR product was digested with $1 \mathrm{U}$ of BseGI restriction endonuclease (Fermentas) at $55^{\circ} \mathrm{C}$ overnight. After restriction enzyme digestion the normal (TT) genotype gave fragments of $122 \mathrm{bp}$ and $165 \mathrm{bp}$, whereas the homozygous form (CC) was $35 \mathrm{bp}, 87 \mathrm{bp}, 165 \mathrm{bp}$.

PCR conditions (PTC-200, Bio-Rad, Hercules, CA, USA) were similar for both methods: 2 min initial denaturation at $96^{\circ} \mathrm{C}, 35$ cycles of $20 \mathrm{~s}$ at $96^{\circ} \mathrm{C} ; 20 \mathrm{~s}$ at $60^{\circ} \mathrm{C} ; 20 \mathrm{~s}$ at $72^{\circ} \mathrm{C}$ and the final extension at $72^{\circ} \mathrm{C}$ for $5 \mathrm{~min}$. The amplification was carried out in a final volume of $50 \mu 1$ containing $5 \mu \mathrm{l}$ reaction buffer $(500 \mathrm{mmol} / \mathrm{L} \mathrm{KCl}, 14 \mathrm{mmol} / \mathrm{L}$ $\mathrm{MgCl}_{2}, 10 \mathrm{mmol} / \mathrm{L}$ Tris- $\left.\mathrm{HCl}, \mathrm{pH} 9.0\right), 1 \mu 150 \mathrm{mmol} / \mathrm{L}$ $\mathrm{MgCl}_{2}, 0.2 \mathrm{mmol} / \mathrm{L}$ of each dNTP, $1 \mathrm{U}$ of Taq polymerase, $0.2 \mathrm{mmol} / \mathrm{L}$ of each reaction specific primer and $1 \mu \mathrm{g}$ DNA.

\section{Statistical Analysis}

Results are expressed as mean \pm SEM. Statistical significance was assessed by the Mann-Whitney U test to compare the differences between groups. Chi-square tests were used to compare qualitative data. Multiple logistic regression analysis was carried out to evaluate the effect of the APOA5 genotype on the development of metabolic syndrome. A value of $\mathrm{p}<0.05$ was considered statistically significant. All statistical analyses were performed by using the SPSS 11.0 software (SPSS Inc, Chicago, IL, USA). 
Table 3 Multiple Logistic Regression Analysis for the Association Between Carrying IVS3 + 476A and 1259C Allelic Variants and Risk for Metabolic Syndrome

\begin{tabular}{lcccc}
\hline \hline Genotypes & $\begin{array}{c}\text { Metabolic syndrome patients } \\
(n=213)\end{array}$ & $\begin{array}{c}\text { Controls } \\
(n=142)\end{array}$ & $\begin{array}{c}\text { Unadjusted model OR } \\
(95 \% \text { CI })\end{array}$ & $\begin{array}{c}\text { Adjusted model OR } \\
(95 \% \text { CI }) *\end{array}$ \\
\hline IVS3+G476A & & & & \\
$\quad$ Non-carrier $(G G)$ & $84.5 \%$ & $95.1 \%{ }^{\#}$ & $3.503(1.503-8.162)$ & $3.529(1.308-9.029)$ \\
Carrier $(G A+A A)$ & $15.5 \%$ & $4.9 \%$ & $p=0.004$ & $p=0.009$ \\
T1259C & $84.0 \%$ & $84.5 \%$ & $1.064(0.583-1.939)$ & $0.971(0.509-1.854)$ \\
Non-carrier $(T T)$ & $16.0 \%$ & $15.5 \%$ & $p=0.840$ & $p=0.929$ \\
Carrier $(T C+C C)$ & & & & \\
\hline
\end{tabular}

OR, odds ratio; $C I$, confidence interval.

*Adjusted for age, gender, total serum cholesterol, acute myocardial infarction, and stroke.

${ }^{\#} p<0.001$

\section{Results}

Major clinical parameters of the patients with metabolic syndrome and controls are summarized in Table 1 . Serum triglycerides and BMI were significantly elevated in patients with metabolic syndrome compared with controls $(\mathrm{p}<0.001)$. The serum total cholesterol did not differ between the 2 groups.

The genotype distributions with their association with triglycerides are shown in Table 2. The genotypes were in Hardy-Weinberg distribution in both groups. The IVS3+ $476 \mathrm{~A}$ allelic variant was associated with increased serum triglycerides compared with non-carriers in both metabolic syndrome patients and the controls; similarly, the 1259C variant was also associated with elevated triglyceride levels. The serum total cholesterol of the patients was similar for all genotypes.

The IVS3+476A allele frequency was $8.05 \%$ in the metabolic syndrome patients and $2.47 \%$ in the controls $(\mathrm{p}<0.001$, data not shown), and there was no difference between the 2 groups in distribution of $1259 \mathrm{C}$ allele frequency $(8.29 \mathrm{vs}$ $7.52 \%$; data not shown).

Multiple regression analysis revealed that carrying the IVS3+476A allelic variant confers an increased risk for developing metabolic syndrome (Table 3 ). The model adjusted for age, gender, total serum cholesterol, acute myocardial infarction and stroke confirmed the association. Analyzing the $1259 \mathrm{C}$ allelic variant showed no association of the allele with metabolic syndrome.

\section{Discussion}

APOA5 regulates lipid metabolism through at least 2 major mechanisms. First, it can inhibit the hepatic production of VLDL, and $2^{\text {nd }}$, it can increase the activity of lipoprotein lipase, resulting in decreased serum triglyceride levels 16,17 Different naturally occurring polymorphisms of APOA5, such as T-1131C, T1259C and C56G, have been previously shown to influence the genetic expression of lipoproteins, resulting ultimately in elevation of the serum triglyceride levels! ${ }^{10,18-20}$

Several studies have provided evidence that naturally occurring variants of $A P O A 5$ are associated with elevated triglycerides (ie, T-1131C, IVS3+G476A, T1259C, C56G). In addition, some of these were found to confer risk for the development of coronary artery disease in different populations. Several studies revealed that the $-1131 \mathrm{C}, 56 \mathrm{G}$ and 1259C variants of APOA5 are susceptibility SNPs for the development of cardiovascular and cerebrovascular diseases in Chinese, European Whites, Indians and Afro-
Carribeans?,13,22-26 Previous studies described 2 SNPs of APOA5 (-1131C and 56G) associated with hypertriglyceridemia, cardiovascular disease and risk for atherosclerosis in American populations ${ }^{7}$ and in European Caucasian populations, $4,7,8,27,28$ Studies of Europeans and Middle-Americans have found relationships between serum triglycerides and the abovementioned APOA5 variants, but they did not support that SNPs of APOA5 independently confer risk for coronary artery diseases, 929,30 Moreover, the T-1131C allelic variant of $A P O A 5$ was recently reported to be associated with the metabolic syndrome in Japanese and Romanian populations, ${ }^{4} 11$ The aim of the current study was to investigate the effect of the IVS3+476A and $1259 \mathrm{C}$ variants on triglyceride metabolism, and to extend the observations as a case-control association study for these SNPs to investigate their relationship with development of metabolic syndrome.

Metabolic syndrome is a complex disorder composed of obesity, elevated triglyceride levels, decreased HDL-C, raised systolic and diastolic blood pressures and impaired glucose metabolism!,31 Elevated serum triglyceride levels, which are 1 of the major hallmarks of metabolic syndrome, are influenced by several exogenous factors, such as diet, smoking or alcohol consumption. In the present study, the serum triglyceride level and the BMI were significantly higher in the metabolic syndrome patients compared with the controls. We found elevated triglycerides in carriers of the IVS3+476A and 1259C variants in both the metabolic syndrome and control groups, although these genotypes did not affect the total serum cholesterol levels. In metabolic syndrome patients there was an approximately 3.3-fold accumulation in the IVS3+476A allelic variant, whereas no difference was found in the distribution of the $1259 \mathrm{C}$ variants between the patients and controls. By logistic regression analysis we found a strong association between the IVS3+476A variant, but not for the $1259 \mathrm{C}$ variant, and the development of metabolic syndrome; thus, the present results revealed that carrying the IVS3+476A allele, but not the $1259 \mathrm{C}$ variant, confers independent risk for the metabolic syndrome. This means that elevated triglyceride levels cannot be the only determinant of the risk effect, because both of them were associated with elevated triglycerides. Therefore, another mechanism of action cannot be ruled out.

Recent observations have revealed that certain SNPs $(-1131 \mathrm{C}, 56 \mathrm{G})$ of $A P O A 5$ are in linkage disequilibrium with $A P O C 3$ variants, which play a major role in the development of insulin resistance, because in its promoter region an insulin-responsive element was identified,29,32,33 Two SNPs (T-455C and C-482T) in the distal promoter region 
of $A P O C 3$ were found to be associated with reduced affinity for the nuclear transcription factors mediating the downregulating response to insulin9,10,33,34 The 2 SNPs of APOA5 are in different linkage with other SNPs of the APOAICIII-AIV gene cluster. It is possible that the IVS3+476A allele is in stronger linkage with the SNPs of this cluster influencing serum triglycerides and carbohydrate metabolism than the $1259 \mathrm{C}$; however, this assumption has to be confirmed.

\section{Acknowledgments}

This work was supported by a grant from the Hungarian Scientific Research Foundation OTKA T 49589, and a grant from the Hungarian Ministry of Health ETT 497/2006.

\section{References}

1. Eckel RH, Grundy SM, Zimmet PZ. The metabolic syndrome. Lancet 2005; 365: 1415-1428.

2. Assmann G, Guerra R, Fox G, Cullen P, Schulte H, Willett D, et al. Harmonizing the definition of the metabolic syndrome: Comparison of the criteria of the Adult Treatment Panel III and the International Diabetes Federation in United States American and European populations. Am J Cardiol 2007; 99: 541-548.

3. Connelly PW, Petrasovits A, Stachenko S, MacLean DR, Little JA, Chockalingam A. Prevalence of high plasma triglyceride combined with low HDL-C levels and its association with smoking, hypertension, obesity, diabetes, sedentariness and LDL-C levels in the Canadian population: Canadian Heart Health Surveys Research Group. Can J Cardiol 1999; 15: 428-433.

4. Yamada Y, Kato K, Hibino T, Yokoi K, Matsuo H, Segawa T, et al. Prediction of genetic risk for metabolic syndrome. Atherosclerosis 2007; 191: 298-304.

5. Park YW, Zhu S, Palaniappan L, Heshka S, Carnethon MR, Heymsfield SB. The metabolic syndrome: Prevalence and associated risk factor findings in the US population from the Third National Health and Nutrition Examination Survey, 1988-1994. Arch Intern Med 2003; 163: 427-436.

6. Grundy SM. Metabolic syndrome: A multiplex cardiovascular risk factor. J Clin Endocrinol Metab 2007; 92: 399-404.

7. Elosua R, Ordovas JM, Cupples LA, Lai CQ, Demissie S, Fox CS, et al. Variants at the APOA5 locus, association with carotid atherosclerosis, and modification by obesity: The Framingham Study. J Lipid Res 2006; 47: 990-996.

8. Dallongeville J, Cottel D, Montaye M, Codron V, Amouyel P, Helbecque N. Impact of APOA5/A4/C3 genetic polymorphisms on lipid variables and cardiovascular disease risk in French men. Int $J$ Cardiol 2006; 106: 152-156.

9. Martinelli N, Trabetti E, Bassi A, Girelli D, Friso S, Pizzolo F, et al. The $-1131 \mathrm{~T}>\mathrm{C}$ and S19W APOA5 gene polymorphisms are associated with high levels of triglycerides and apolipoprotein C-III, but not with coronary artery disease: An angiographic study. Atherosclerosis 2007; 191: 409-417.

10. Martin S, Nicaud V, Humphries SE, Talmud PJ. Contribution of APOA5 gene variants to plasma triglyceride determination and to the response to both fat and glucose tolerance challenges. Biochim Biophys Acta 2003; 1637: 217-225.

11. Niculescu LS, Fruchart-Najib J, Fruchart JC, Sima A. Apolipoprotein A-V gene polymorphisms in subjects with metabolic syndrome. Clin Chem Lab Med 2007; 45: 1133-1139.

12. Matsunaga A, Arishima H, Niimura H, Zhang B, Uehara Y, Ohwaki $\mathrm{K}$, et al. Strong linkage disequilibrium and association of $-1131 \mathrm{~T}>\mathrm{C}$ and c.553G $>\mathrm{T}$ polymorphisms of the apolipoprotein A5 gene with hypertriglyceridemia in a Japanese population. Circ J 2007; 71: $746-752$.

13. Havasi V, Szolnoki Z, Talian G, Bene J, Komlosi K, Maasz A, et al. Apolipoprotein A5 gene promoter region T-1131C polymorphism associates with elevated circulating triglyceride levels and confers susceptibility for development of ischemic stroke. J Mol Neurosci 2006; 29: 177-183.

14. Maász A, Kisfali P, Horvatovich K, Mohás M, Markó L, Csöngei V, et al. Apolipoprotein A5 T-1131C variant confers risk for metabolic syndrome. Pathol Oncol Res 2007; 13: 243-247.
15. Deedwania PC, Hunninghake DB, Bays H. Effects of lipid-altering treatment in diabetes mellitus and the metabolic syndrome. Am J Cardiol 2004; 93: 18-26.

16. Marcais C, Verges B, Charriere S, Pruneta V, Merlin M, Billon S, et al. Apoa5 Q139X truncation predisposes to late-onset hyperchylomicronemia due to lipoprotein lipase impairment. J Clin Invest 2005; 115: $2862-2869$.

17. Merkel M, Heeren J. Give me A5 for lipoprotein hydrolysis! J Clin Invest 2005; 115: 2694-2696.

18. Talmud PJ, Hawe E, Martin S, Olivier M, Miller GJ, Rubin EM, et al. Relative contribution of variation within the APOC3/A4/A5 gene cluster in determining plasma triglycerides. Hum Mol Genet 2002; 11: $3039-3046$.

19. Kao JT, Wen HC, Chien KL, Hsu HC, Lin SW. A novel genetic variant in the apolipoprotein A5 gene is associated with hypertriglyceridaemia. Hum Mol Genet 2003; 12: 2533-2539.

20. Pennacchio LA, Olivier M, Hubacek JA, Krauss RM, Rubin EM, Cohen JC. Two independent apolipoprotein A5 haplotypes influence human plasma triglyceride levels. Hum Mol Genet 2002; 11: 3031 3038.

21. Pennacchio LA, Olivier M, Hubacek JA, Cohen JC, Cox DR, Fruchart JC, et al. An apolipoprotein influencing triglycerides in humans and mice revealed by comparative sequencing. Science 2001; 294: 169-173.

22. Szalai C, Keszei M, Duba J, Prohaszka Z, Kozma GT, Csaszar A, et al. Polymorphism in the promoter region of the apolipoprotein A5 gene is associated with an increased susceptibility for coronary artery disease. Atherosclerosis 2004; 173: 109-114.

23. Tang Y, Sun P, Guo D, Ferro A, Ji Y, Chen Q, et al. A genetic variant c.553G $>\mathrm{T}$ in the apolipoprotein $\mathrm{A} 5$ gene is associated with an increased risk of coronary artery disease and altered triglyceride levels in a Chinese population. Atherosclerosis 2006; 185: 433-437.

24. Hsu LA, Ko YL, Chang CJ, Hu CF, Wu S, Teng MS, et al. Genetic variations of apolipoprotein A5 gene is associated with the risk of coronary artery disease among Chinese in Taiwan. Atherosclerosis 2006; 185: 143-149.

25. Dorfmeister B, Cooper JA, Stephens JW, Ireland H, Hurel SJ, Humphries SE, et al. The effect of APOA5 and APOC3 variants on lipid parameters in European Whites, Indian Asians and AfroCaribbeans with type 2 diabetes. Biochim Biophys Acta 2007; 1772: $355-363$.

26. Bi N, Yan SK, Li GP, Yin ZN, Chen BS. A single nucleotide polymorphism -1131T $>\mathrm{C}$ in the apolipoprotein $\mathrm{A} 5$ gene is associated with an increased risk of coronary artery disease and alters triglyceride metabolism in Chinese. Mol Genet Metab 2004; 83: 280-286.

27. Lai CQ, Demissie S, Cupples LA, Zhu Y, Adiconis X, Parnell LD, et al. Influence of the APOA5 locus on plasma triglyceride, lipoprotein subclasses, and CVD risk in the Framingham Heart Study. J Lipid Res 2004; 45: 2096-2105.

28. Talmud PJ, Martin S, Taskinen MR, Frick MH, Nieminen MS, Kesaniemi YA, et al. APOA5 gene variants, lipoprotein particle distribution, and progression of coronary heart disease: Results from the LOCAT study. J Lipid Res 2004; 45: 750-756.

29. Ruiz-Narvaez EA, Yang Y, Nakanishi Y, Kirchdorfer J, Campos H. APOC3/A5 haplotypes, lipid levels, and risk of myocardial infarction in the Central Valley of Costa Rica. J Lipid Res 2005; 46: $2605-$ 2613.

30. Lee KW, Ayyobi AF, Frohlich JJ, Hill JS. APOA5 gene polymorphism modulates levels of triglyceride, HDL cholesterol and FERHDL but is not a risk factor for coronary artery disease. Atherosclerosis 2004; 176: $165-172$.

31. Cameron AJ, Shaw JE, Zimmet PZ. The metabolic syndrome: Prevalence in worldwide populations. Endocrinol Metab Clin North Am 2004; 33: $351-375$.

32. Wright WT, Young IS, Nicholls DP, Patterson C, Lyttle K, Graham CA. SNPs at the APOA5 gene account for the strong association with hypertriglyceridaemia at the APOA5/A4/C3/A1 locus on chromosome $11 \mathrm{q} 23$ in the Northern Irish population. Atherosclerosis 2006; 185: $353-360$.

33. Groenendijk M, Cantor RM, de Bruin TW, Dallinga-Thie GM. The apoAI-CIII-AIV gene cluster. Atherosclerosis 2001; 157: 1-11.

34. Waterworth DM, Talmud PJ, Luan J, Flavell DM, Byrne CD, Humphries SE, et al. Variants in the APOC3 promoter insulin responsive element modulate insulin secretion and lipids in middle-aged men. Biochim Biophys Acta 2003; 1637: 200-206. 